\title{
Article \\ Impacts of Ground Fissures on Soil Properties in an Underground Mining Area on the Loess Plateau, China
}

\author{
Jiaxin Mi ${ }^{1,2}$, Yongjun Yang ${ }^{2,3}$, Huping Hou ${ }^{2,3}$, Shaoliang Zhang ${ }^{2,3, * \mathbb{C}}$, Zhongyi Ding ${ }^{1}$ and Yifei Hua ${ }^{4}$ \\ 1 School of Public Policy and Management, China University of Mining and Technology, Xuzhou 221008, China; \\ jxmi@cumt.edu.cn (J.M.); dingzhongyi@cumt.edu.cn (Z.D.) \\ 2 Engineering Research Center of Ministry of Education for Mine Ecological Restoration, China University of \\ Mining and Technology, Xuzhou 221116, China; y.yang@cumt.edu.cn (Y.Y.); houhuping@cumt.edu.cn (H.H.) \\ 3 School of Environment Science and Spatial Informatics, China University of Mining and Technology, \\ Xuzhou 221008, China \\ 4 School of Management and Economics, China University of Mining and Technology, Xuzhou 221008, China; \\ yfhua@cumt.edu.cn \\ * Correspondence: slzhang@cumt.edu.cn; Tel.: +86-139-5220-1918
}

Citation: Mi, J.; Yang, Y.; Hou, H.; Zhang, S.; Ding, Z.; Hua, Y. Impacts of Ground Fissures on Soil Properties in an Underground Mining Area on the Loess Plateau, China. Land 2022, 11, 162. https://doi.org/10.3390/ land 11020162

Received: 9 December 2021

Accepted: 16 January 2022

Published: 20 January 2022

Publisher's Note: MDPI stays neutral with regard to jurisdictional claims in published maps and institutional affiliations.

Copyright: (C) 2022 by the authors. Licensee MDPI, Basel, Switzerland. This article is an open access article distributed under the terms and conditions of the Creative Commons Attribution (CC BY) license (https:// creativecommons.org/licenses/by/ $4.0 /)$.

\begin{abstract}
Mining-induced ground fissures are the main type of geological disasters found on the Loess Plateau, China, and cause great impacts on the soil properties around ground fissures. However, little research has been conducted on the quantitative relationship between ground fissures and changes in soil properties. To address this, 40 ground fissures in the Yungang mining area, Datong City, Shanxi Province, China, were investigated, and changes in soil properties (soil organic matter, soil moisture, field capacity, bulk density, soil porosity, and grain compositions) were revealed by the difference in soil properties between the edge and contrast points around ground fissures. Redundancy analyses were used to illustrate the relationships between the value (Si_DV) and percentage (Si_DP) of the difference in soil properties between the edge and contrast points, as well as the ground fissures. The characteristics of ground fissures that had a significant correlation according to Pearson correlation analysis with Si_DP were selected and analyzed via multivariate linear fitting model, random forest model, and Back Propagation (BP) neural network model, respectively. Results show that soil organic matter, soil moisture content, bulk density, field capacity, and the content of clay at the edge points were significantly less than those at the contrast points; conversely, soil porosity at the edge points was significantly greater. The average percentage of the difference between the edge points and contrast points of ground fissures in these six properties was $15.27 \%$, while soil moisture content showed the greatest change $(20.65 \%)$. The Si_DP was significantly correlated with the width, slope, and vegetation coverage of ground fissures; however, the vegetation coverage was the determining factor. BP neural network model had the greatest performance in revealing the relationships between ground fissures and changes in soil properties. The model for soil organic matter had the highest accuracy $\left(R^{2}=0.89\right)$, and all others were above 0.5 . This research provides insights into the quantitative relationship between ground fissures and their impacts on soil physical properties, which can be used in conjunction with remote sensing images to rapidly assess soil erosion risks caused by mining on a large scale, given that soil physical properties are closely related to topsoil stability.
\end{abstract}

Keywords: ground fissures; soil physical properties; underground mining; Loess Plateau; quantitative relationships

\section{Introduction}

Underground mining has caused large-scale land subsidence and surface deformation, leaving a large number of ground fissures in some mining areas [1-4]. These ground fissures often destroy the original landscape, and lead to changes in soil properties by accelerating soil erosion from rainfall, runoff, and wind [5,6]. On the Loess Plateau of China, adverse environmental conditions and severe soil erosion often cause quite obvious 
soil degradation $[7,8]$. Therefore, giving insight into quantitative relationships between ground fissures and changes in soil properties is particularly important for the ecological assessment of a mining area.

Ground fissures have often initiated the alteration of various soil properties. Soil moisture would decrease significantly due to the increasing rate of evaporation, because ground fissures can cause large areas of bare land $[9,10]$. From a regional perspective, the soil moisture in areas with ground fissures was significantly lower than that of unmined areas [11]; locally, the soil moisture on both sides of a ground fissure showed a trend of initially decreasing and then increasing in the vertical direction while increasing in the horizontal direction within $1.2 \mathrm{~m}$ of a ground fissure [12,13]. The grain compositions and hydraulic properties of soil near a ground fissure were also changed by the impacts of erosion caused by rain [14]. The content of clay and silt was likely to decrease, while the sand content would likely increase significantly [15]. The soil hydraulic properties in areas with mine subsidence were found to degenerate, including a decrease in field capacity and bulk density, as well as an increase in soil porosity [16]. In addition, ground fissures led an increase in the loss of soil nutrients with runoff flowing deep into the soil, leading to a decrease in the amounts of soil organic matter, total nitrogen, and total phosphorus on both sides of a ground fissure [17-19]. In addition, soil degradation would limit the growth and development of nearby plant communities, further aggravating the changes in soil properties [20,21].

The changes in soil properties induced from ground fissures mainly comes from the alteration in hydrogeological processes, which are influenced by multiple characteristics of ground fissures [22,23]. Some research has indicated that the width and density of ground fissures are significantly correlated with the change of soil moisture, cohesion, and organic matter [24], by determining the rate and direction of runoff around ground fissures [25]. However, little research has demonstrated the existence of quantitative relationships between ground fissures and changes in soil properties, which is a prerequisite to evaluating mining damage on environment on a large scale. The existing difficulty mainly is the quantitative evaluation of changes in soil properties induced from ground fissures. There are differences in various environmental factors such as terrain and vegetation between unmined and mined areas with subsidence, which also could result in changes in soil properties. Therefore, the quantitative relationship between ground fissures and changes in soil properties is still lacking.

The present study aimed to demonstrate quantitative relationships between ground fissures and changes in soil properties. The Yungang mining area, Datong City, Shanxi Province, China, was selected as the study area. The present study had two objectives: (1) to investigate impacts of ground fissures on soil properties; (2) to determine the quantitative relationship between ground fissures and changes in soil properties.

\section{Materials and Methods}

\subsection{Study Area}

The research was conducted in the Yungang mining area, located in the Yungang District, Datong City, Shanxi Province, China (Figure 1). Here, the semi-arid continental climate features a mean annual temperature of $6.4^{\circ} \mathrm{C}$ and a mean annual precipitation of $384.6 \mathrm{~mm}$ with precipitation mainly occurring from June to September. The loess soil here is typically composed of approximately $64 \%$ sand $(50-2000 \mu \mathrm{m}), 24 \%$ silt $(2-50 \mu \mathrm{m})$, and $12 \%$ clay $(<2 \mu \mathrm{m})$. The Pingchuan Hills dominate the area, while the elevation is generally high in the northwest and low in the southeast, with an average elevation of $1250 \mathrm{~m}$. This area with coal mining subsidence covers five areas including the townships of Pingwang, Kouquan, and Ya'er Cliff and towns of Gaoshan and Yungang, or a total area of $459.37 \mathrm{~km}^{2}$. 


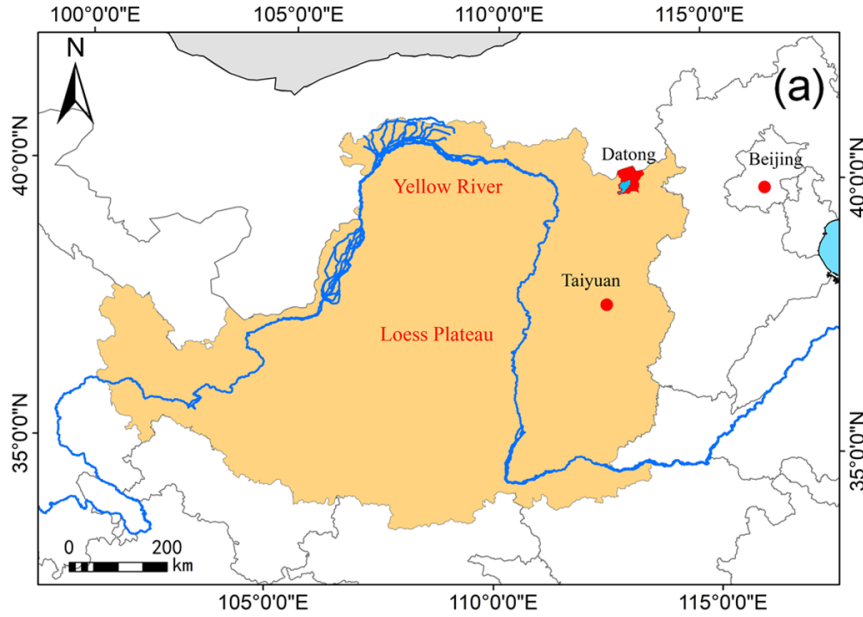

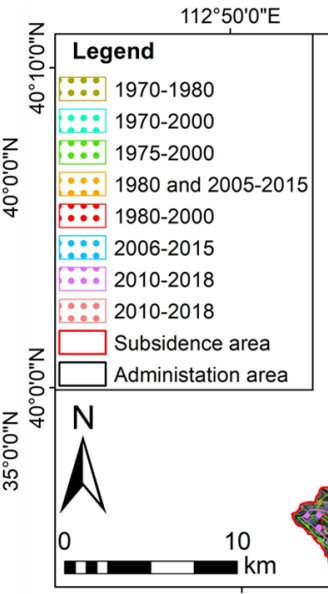

$112^{\circ} 50^{\prime} \mathrm{O}^{\prime \prime F}$ $113^{\circ} \mathrm{O}^{\prime} \mathrm{O}^{\prime} \mathrm{E}$

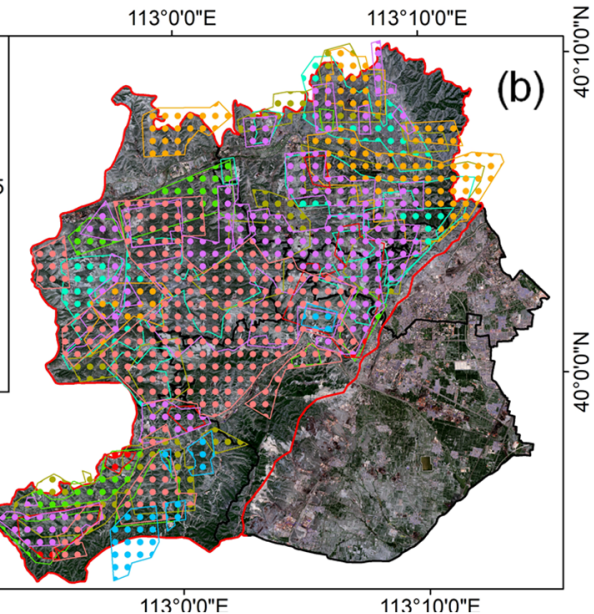

Figure 1. Locations of (a) the Yungang mining area within the Loess Plateau of China and (b) the distribution of the subsidence area. The boxes with years in legend represent the durations of mining activities occurring in each area.

A long history of coal mining in the Yungang mining area can be traced back 1500 years. By the end of 2000, 191 coal-mining enterprises were active in the southern suburbs. After coal mine consolidation efforts were completed in 2010, a total of 43 coal mines were retained having a total production capacity of 57.08 million tons annually. Between 1949 and 2003, the cumulative coal mine output reached 113.2 million tons in total. The large-scale mining of coal has led to a large area of subsidence that, as of 2015 , involved $331.59 \mathrm{~km}^{2}$ [26]. In this study, one subsidence area located in the central part of the Yungang mining area, which appeared in 2001 after underground mining, was selected. A large number of ground fissures occurred there, with similar conditions in soil types, plant communities, and development direction. Thus, these ground fissures were selected and nearby soil was investigated to reveal changes in soil properties in the study area.

\subsection{Field Surveys and Soil Samples}

A total of 40 ground fissures were found in the area of subsidence (Figure 2a), which all belong to tensile ones according to the classification of ground fissures, and five characteristics of these ground fissures, including the width, depth, length, slope, and vegetation coverage, were investigated. The width, depth, and length of each ground fissure were measured by tape and rope; the slope of each ground fissure was measured via a JZC-B2 Inclinometer (NI Instrument, Wenzhou, China), with one degree of measurement accuracy. Because herb communities dominated all areas near ground fissures, the average of vegetation coverage was measured by counting the number of herbs in a series of $1 \mathrm{~m} \times 1 \mathrm{~m}$ quadrats (Figure $2 \mathrm{~b}$ ) and calculating with the approximate area of herb cover. A detailed information of the characteristics of ground fissures was shown in the Table S1 of the supplement material.

Two kind of sample points, an edge point of and a contrast point near each ground fissure, were selected to calculate the changes in soil properties induced by ground fissures (Figure $2 b$ ). The edge point was defined as a point at the edge of a ground fissure, while the contrast point was $1 \mathrm{~m}$ away from the edge point horizontally. On steep slopes, contrast points were selected $1 \mathrm{~m}$ above ground fissures from edge points. Two soil core samples were collected via cutting rings (volume $100 \mathrm{~cm}^{3}$, inner diameter $5 \mathrm{~cm}$ ) horizontally at a depth of 2.5-7.5 cm approximately after removing surface plant, residue, and soil (about $2.5 \mathrm{~cm}$ ) at each edge point and contrast point of ground fissures. One soil core sample was used to determine the soil moisture content (SMC), bulk density (BD), field capacity (FC), and soil porosity (SP), and another soil sample was used to determine the soil organic matter (SOM) content and soil grain compositions. Each soil sample was weighed and documented immediately after collection. At each ground fissure, three edge points and 
contrast points were selected at each ground fissure as three pseudo-replicates, and the mean of three pseudo-replicates was used to represent the average value of changes in soil properties, and thus 240 sample points were investigated in total.

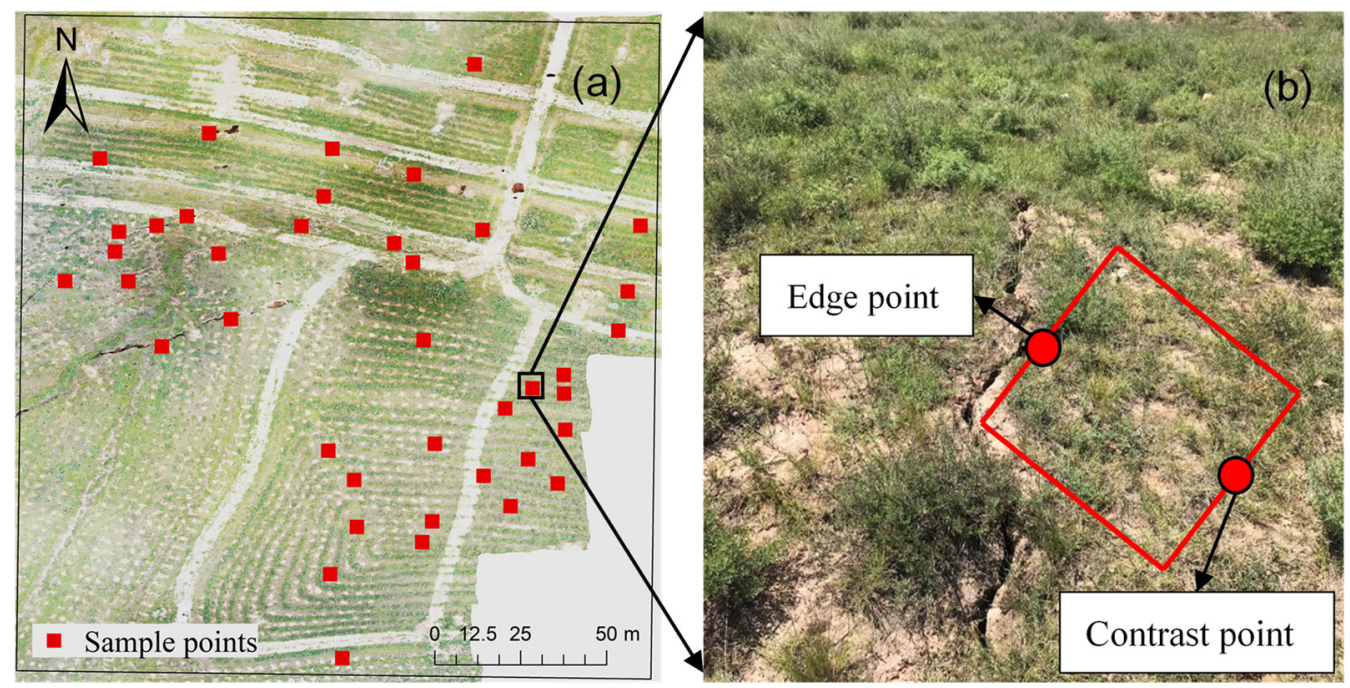

Figure 2. (a) The distribution of ground fissures in a subsidence area, and (b) illustration of the edge point and contrast point of one ground fissure. The red squires in $(\mathbf{a}, \mathbf{b})$ represent the sample points, including both edge and contrast points, at each investigated ground fissures.

\subsection{Laboratory Analysis}

Soil physical properties and grain compositions were analyzed by indoor experiments with the collected soil sample. The SMC, BD, and SP were determined by the cutting ring method; FC was measured using the Wilcox method [27]; SOM was analyzed according to the $\mathrm{K}_{2} \mathrm{Cr}_{2} \mathrm{O}_{7}-\mathrm{H}_{2} \mathrm{SO}_{4}$ oxidation method [28]. Soil grain compositions were determined by a BT-9300Z Laser Diffraction Particle Size Analyzer (Bettersize, Dandong, China), with the measuring range from 0.1 to $1250 \mu \mathrm{m}$; soil particles were classified into three categories: clay $(<0.002 \mathrm{~mm})$, silt $(0.002-0.02 \mathrm{~mm})$, and sand $(0.02-2.0 \mathrm{~mm})$ according to the size of each particle; the mass fractal dimension $(D)$ was calculated using an equation from [29]:

$$
D=3-\frac{\log \left[M\left(r<R_{i}\right) / M_{T}\right]}{\log \left[R_{i} / R_{\max }\right]}
$$

where $M$ is the cumulative mass of particles of the $i$ th size, $r$ is less than $R_{i}, M_{T}$ is the total mass, $R_{i}$ is the mean particle diameter $(\mathrm{mm})$ of the $i$ th size class, and $R_{\max }$ is the mean diameter of the largest particle.

\subsection{Statistic Analysis}

All of the data collected from each site are presented as the mean of 40 replications. Kolmogorov-Smirnoff test and Levene's test at the 0.05 level were used to check for normality and homogeneity of the variances of the data, and all variables followed a normal distribution. One-way analysis of variance was performed to analyze the variation of the soil properties, compositions, and fractal dimensions among the edge and contrast points of all ground fissures. Significant differences between the different mine dumps were evaluated at the 0.05 level with a Duncan test. The value $\left(S_{i \_} D V\right)$ and percentage $\left(S_{i \_} D P\right)$ of the difference in soil properties between the edge and contrast points were developed to reveal changes in soil properties induced from ground fissures, and the $S_{i}$ DV and $S_{\text {i__ }} D P$ between the edge and contrast points were calculated as:

$$
\mathrm{S}_{\mathrm{i} \_} \mathrm{DV}=\mathrm{S}_{\mathrm{i} \_} \mathrm{CP}-\mathrm{S}_{\mathrm{i} \_} \mathrm{EP}
$$




$$
\mathrm{S}_{\mathrm{i}_{\mathrm{DP}}}=\frac{\mathrm{S}_{\mathrm{i}_{\mathrm{CP}}}-\mathrm{S}_{\mathrm{i}_{\mathrm{EP}}}}{\mathrm{S}_{\mathrm{i}_{\mathrm{CP}}}} \times 100 \%
$$

where $\mathrm{S}_{\mathrm{i}_{-}} \mathrm{CP}$ and $\mathrm{S}_{\mathrm{i}_{-}} \mathrm{EP}$ are the $i$ th soil property at the contrast and edge points.

Pearson correlation analysis was used to show the correlation between all variables. Redundancy analysis was selected to illustrate the relationships between all $\mathrm{S}_{\mathrm{i}} \mathrm{DV}$ and $\mathrm{S}_{\mathrm{i}-} \mathrm{DP}$, and characteristics of the ground fissures, according to results of Detrended Correspondence Analysis. The characteristics of ground fissures that had a significant correlation with $\mathrm{S}_{\mathrm{i}_{-}} \mathrm{DV}$ and $\mathrm{S}_{\mathrm{i}-\mathrm{DP}}$ were selected and analyzed via multivariate linear fitting model, random forest model and BP neural network model, respectively. Multivariate linear fitting model and Random Forest model were developed the package in R software, while BP neural network model was determined in Matlab. The numbers of input and output layer neurons are 3 and 1, corresponding to three characteristics of ground fissures (width, slope and vegetation coverage) and each soil properties correlated with ground fissures, respectively. The number of hidden neurons for each soil property ranged from 4 to 12 according to existing empirical formula, and was determined by comparing the accuracy of the model with different numbers of hidden neurons. The coefficient of determination $\left(R^{2}\right)$ was used to show the accuracy performance of three models. All data were analyzed using SPSS 20.0 and CANOCO 5; diagrams were made using Origin 9.

\section{Results}

\subsection{Changes in Soil Properties around Ground Fissures}

The soil properties of edge and contrast points at ground fissures are shown in Figure 3. In terms of the values of SOM, SMC, FC, BD, and clay percentage, characteristics of the edge points of ground fissures were significantly lower than those of contrast points. The soil porosity of edge points was significantly higher than that of contrast points at ground fissures. In addition, the other indicators, including fractal dimension, percentage of silt, and sand, show no significant difference between the edge and contrast points at ground fissures. The $S_{i_{-}} D V$ and $S_{i_{-}} D P$ with significant relationships are shown in Table 1 . In terms of $\mathrm{S}_{\mathrm{i}_{-}} \mathrm{DP}$, the average degree of change in the six soil properties was $15.27 \%$, and the greatest change was the SMC; the FC had the smallest degree of change.

Table 1. The value and percentage of the difference in soil properties impacted by ground fissures.

\begin{tabular}{ccc}
\hline Soil Properties & DV & DP (\%) \\
\hline SOM $(\mathrm{g} / \mathrm{kg})$ & $3.02 \pm 1.3$ & $19.02 \pm 9.11$ \\
SMC $(\%)$ & $2.15 \pm 1.38$ & $20.65 \pm 11.33$ \\
BD $\left(\mathrm{g} / \mathrm{cm}^{3}\right)$ & $0.18 \pm 0.09$ & $13.11 \pm 6.47$ \\
FC $(\%)$ & $4.22 \pm 2.44$ & $11.95 \pm 5.62$ \\
SP & $0.06 \pm 0.01$ & $13.28 \pm 8.44$ \\
Clay (\%) & $0.75 \pm 0.32$ & $13.54 \pm 5.03$ \\
Mean & $/$ & 15.22
\end{tabular}

Note: SOM, soil organic matter; SMC, soil moisture content; BD, bulk density; FC, field capacity; SP, soil porosity; Clay, percent clay; DV, the value of the difference; DP, the percentage of the difference.

\subsection{Correlations between Ground Fissures and Changes in Soil Properties}

The relationships between $\mathrm{S}_{\mathrm{i}_{-}} \mathrm{DV}$ and $\mathrm{S}_{\mathrm{i}_{-}} \mathrm{DP}$, and characteristics of ground fissures are shown in Tables 2 and 3, respectively. Based on the results of the analysis of variance, the $\mathrm{S}_{\mathrm{i}_{-}} \mathrm{DV}$ and $\mathrm{S}_{\mathrm{i}_{-}} \mathrm{DP}$ of the SOM, SMC, BD, FC, SP, and Clay were selected to determine their relationships with ground fissures. All selected soil properties had a significantly positive correlation with the width and slope of ground fissures, while the vegetation coverage of ground fissures was negatively correlated with the $S_{i_{-}} D V$ and $S_{i_{-}} D P$. The values of Pearson correlations between ground fissures and $\mathrm{S}_{\mathrm{i}_{-}} \mathrm{DP}$ were mostly higher than those with $\mathrm{S}_{\mathrm{i}_{-}} \mathrm{DV}$. The depth and length of ground fissures showed no significant relationships with changes in soil properties. 

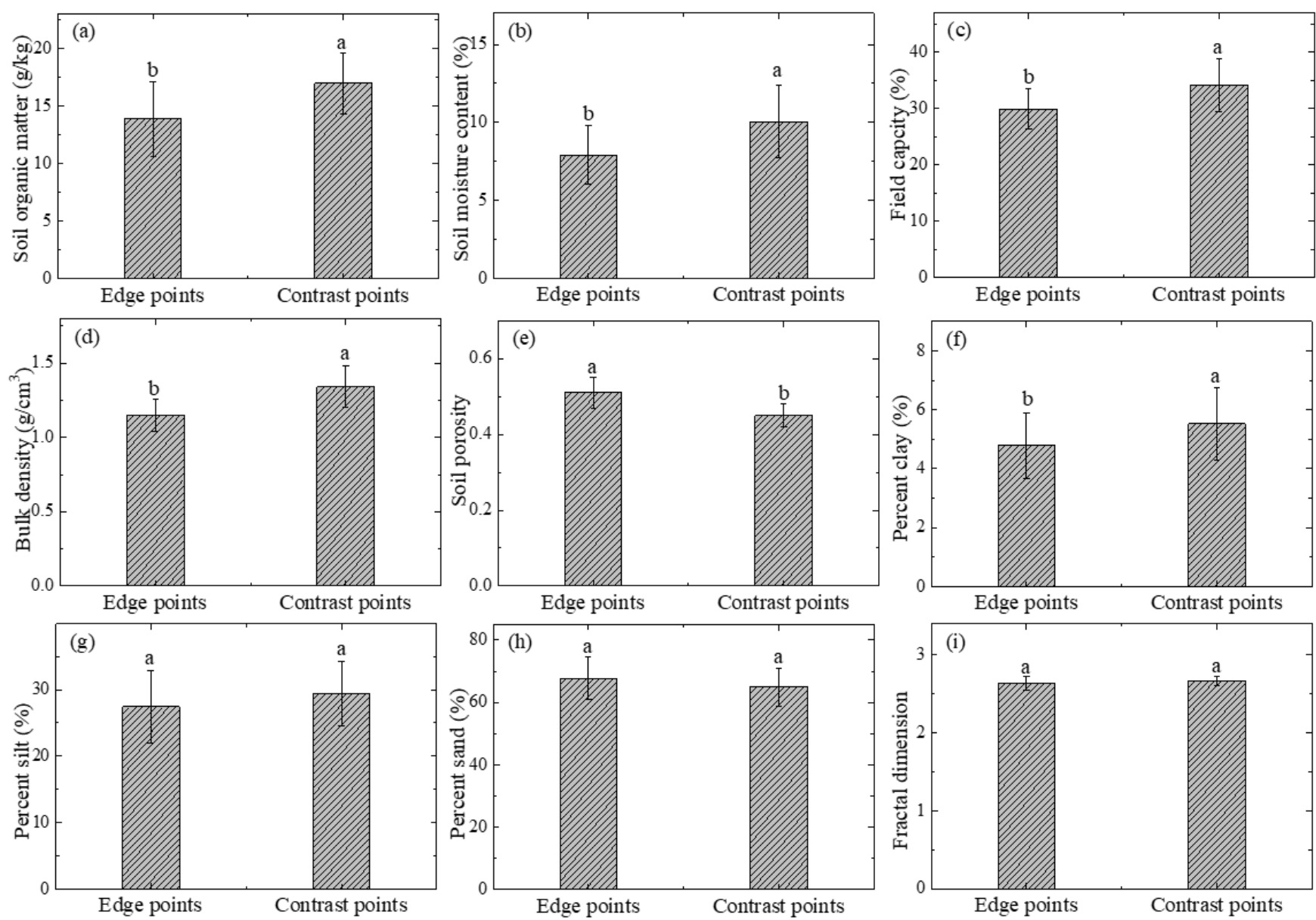

Figure 3. The soil properties of edge and contrast points at ground fissures. (a) Soil organic matter; (b) soil moisture; (c) field capacity; (d) bulk density; (e) soil porosity; (f) percent clay; (g) percent silt; (h) percent sand; (i) fractal dimension. Note: Different letters indicate significant differences among the two points at $p<0.05$ based on Duncan's multiple range tests.

Table 2. The correlations between ground fissures and the percentage of difference in soil properties.

\begin{tabular}{|c|c|c|c|c|c|c|c|c|c|c|}
\hline & Width & Depth & Length & Slope & Coverage & SOM & SMC & BD & FC & SP \\
\hline Depth & -0.020 & 1 & & & & & & & & \\
\hline Length & 0.270 & -0.188 & 1 & & & & & & & \\
\hline Slope & $0.589 * *$ & -0.238 & 0.078 & 1 & & & & & & \\
\hline Coverage & $-0.671^{* *}$ & 0.202 & -0.164 & $-0.621^{* *}$ & 1 & & & & & \\
\hline SOM_DP & $0.664^{* *}$ & -0.224 & 0.153 & $0.422^{* *}$ & $-0.808^{* *}$ & 1 & & & & \\
\hline SMC_DP & $0.634^{* *}$ & -0.215 & 0.285 & $0.616^{* *}$ & $-0.677^{* *}$ & $0.441^{* *}$ & 1 & & & \\
\hline BD_DP & $0.668^{* *}$ & -0.102 & 0.095 & $0.617^{* *}$ & $-0.664^{* *}$ & $0.522 * *$ & $0.599 * *$ & 1 & & \\
\hline FC_DP & $0.600^{* *}$ & -0.144 & 0.175 & $0.423^{* *}$ & $-0.558^{* *}$ & $0.471^{* *}$ & $0.354 *$ & $0.805^{* *}$ & 1 & \\
\hline SP_DP & $0.520 * *$ & -0.264 & 0.263 & $0.648^{* *}$ & $-0.561^{* *}$ & $0.461^{* *}$ & $0.523^{* *}$ & $0.703^{* *}$ & $0.706^{* *}$ & 1 \\
\hline Clay_DP & $0.381 *$ & -0.187 & 0.284 & $0.396^{*}$ & $-0.629^{* *}$ & $0.539 * *$ & $0.455^{* *}$ & $0.574^{* *}$ & $0.461^{* *}$ & $0.558^{* *}$ \\
\hline
\end{tabular}

Note: ${ }^{*}$ and ${ }^{* *}$ indicate significant correlations at $p<0.05$ and $p<0.01$, respectively (two-tailed). SOM, soil organic matter; SMC, soil moisture content; $\mathrm{BD}$, bulk density; FC, field capacity; SP, soil porosity ; Clay, percent clay; DP, the percentage of the difference.

The results of redundancy analysis between Si_DP and Si_DV with characteristics of ground fissures are shown in Figure 4a,b, respectively. After ignoring the factors with relatively small contributions (depth and length), a forward selection was performed. A constrained redundancy analysis showed that selected characteristics of ground fissures explained $74.81 \%$ and $49.6 \%$ of the total variation of Si_DP and Si_DV, respectively. Vegetation coverage and slope contributed $83.1 \%$ and $10.7 \%$ of the total variance of $\mathrm{Si}$ DP, respectively, 
while vegetation coverage and fissure width contributed $87.1 \%$ and $8 \%$ of the total variance of Si_DV, respectively. Both the slope and fissure width showed positive correlations with Si_DP and Si_DV; however, vegetation coverage was negatively correlated with Si_DP and $\mathrm{Si}$ DVV. In summary, the width, slope, and vegetation coverage are the critical characteristics of ground fissures; $\mathrm{Si}$ _DP has a more significant correlation with characteristics of ground fissures than Si_DV.

Table 3. The correlations between ground fissures and the value of difference in soil properties.

\begin{tabular}{|c|c|c|c|c|c|c|c|c|c|c|}
\hline & Width & Depth & Length & Slope & Coverage & SOM & SMC & BD & FC & SP \\
\hline Depth & -0.020 & 1 & & & & & & & & \\
\hline Length & 0.270 & -0.188 & 1 & & & & & & & \\
\hline Slope & $0.589 * *$ & -0.238 & 0.078 & 1 & & & & & & \\
\hline Coverage & $-0.671^{* *}$ & 0.202 & -0.164 & $-0.621^{* *}$ & 1 & & & & & \\
\hline SOM_DV & $0.525^{* *}$ & -0.251 & 0.268 & 0.301 & $-0.587^{* *}$ & 1 & & & & \\
\hline SMC_DV & 0.598 ** & -0.185 & 0.117 & $0.577^{* *}$ & $-0.601^{* *}$ & $0.579 * *$ & 1 & & & \\
\hline BD_DV & $0.710^{* *}$ & -0.104 & 0.140 & $0.601^{* *}$ & $-0.683^{* *}$ & $0.512^{* *}$ & $0.583^{* *}$ & 1 & & \\
\hline FC_DV & $0.524^{* *}$ & -0.090 & 0.125 & 0.393 * & $-0.456^{* *}$ & $0.447^{* *}$ & 0.374 * & $0.748^{* *}$ & 1 & \\
\hline SP_DV & $0.502 * *$ & -0.253 & 0.261 & $0.649^{* *}$ & $-0.540^{* *}$ & 0.299 & $0.498^{* *}$ & $0.691^{* *}$ & $0.699 * *$ & 1 \\
\hline Clay_DV & $0.407^{* *}$ & -0.089 & 0.230 & 0.324 * & $-0.558^{* *}$ & $0.425^{* *}$ & $0.427^{* *}$ & $0.585^{* *}$ & $0.508^{* *}$ & $0.528^{* *}$ \\
\hline
\end{tabular}

Note: ${ }^{*}$ and ${ }^{* *}$ indicate significant correlations at $p<0.05$ and $p<0.01$, respectively (two-tailed). SOM, soil organic matter; SMC, soil moisture content; $\mathrm{BD}$, bulk density; FC, field capacity; SP, soil porosity; Clay, percent clay; DV, the value of the difference.
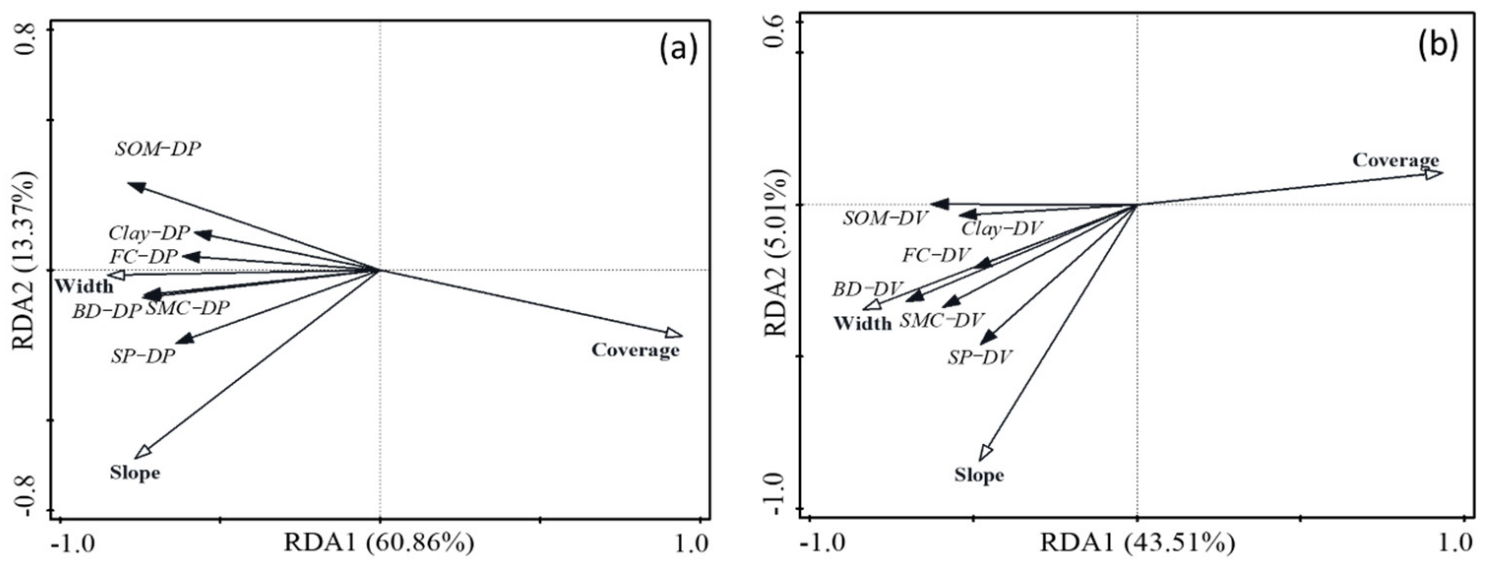

Figure 4. Redundancy analysis (RDA) ordination for the (a) percentage $\left(\mathrm{S}_{\mathrm{i}_{-}} \mathrm{DP}\right)$ and $(\mathbf{b})$ value $\left(\mathrm{S}_{\mathrm{i}_{-}} \mathrm{DV}\right)$ of the difference in soil properties between the edge and contrast points, as well as characteristics of ground fissures. DV and DP represent the value and percentage of the difference in soil properties between the edge points and contrast points, respectively. SOM, soil organic; SMC, soil moisture content; BD, bulk density; FC, field capacity; SP, soil porosity; Clay, percentage of clay.

\subsection{Quantitative Relationships between Ground Fissures and Changes in Soil Properties}

The coefficients of determination of linear fitting model, random forest model and BP neural network model for quantitative relationships between ground fissures and changes in soil properties are shown in Table 4, while the accuracy performance of BP neural network model are shown in Figure 5. The BP neural network model for prediction of the SOM_DP has the highest accuracy $\left(R^{2}=0.8867\right)$ (Figure 5a), followed by the prediction of SP_DP (Figure 5b), BD_DP (Figure 5c), FC_DP (Figure 5d), SMC_DP (Figure 5e), and Clay_DP (Figure 5f). 
Table 4. Coefficients of determination of different models for quantitative relationships between ground fissures and changes in soil properties.

\begin{tabular}{cccc}
\hline $\mathbf{R}^{2}$ & Linear Fitting & Random Forest & BP Neural Network \\
\hline SOM_DP & 0.7041 & 0.5509 & 0.8867 \\
SMC_DP & 0.4685 & 0.3666 & 0.7788 \\
BD_DP & 0.5634 & 0.4064 & 0.7129 \\
FC_DP & 0.4043 & 0.2512 & 0.5658 \\
SP_DP & 0.5522 & 0.4218 & 0.5582 \\
Clay_DP & 0.3991 & 0.1926 & 0.5488 \\
\hline
\end{tabular}
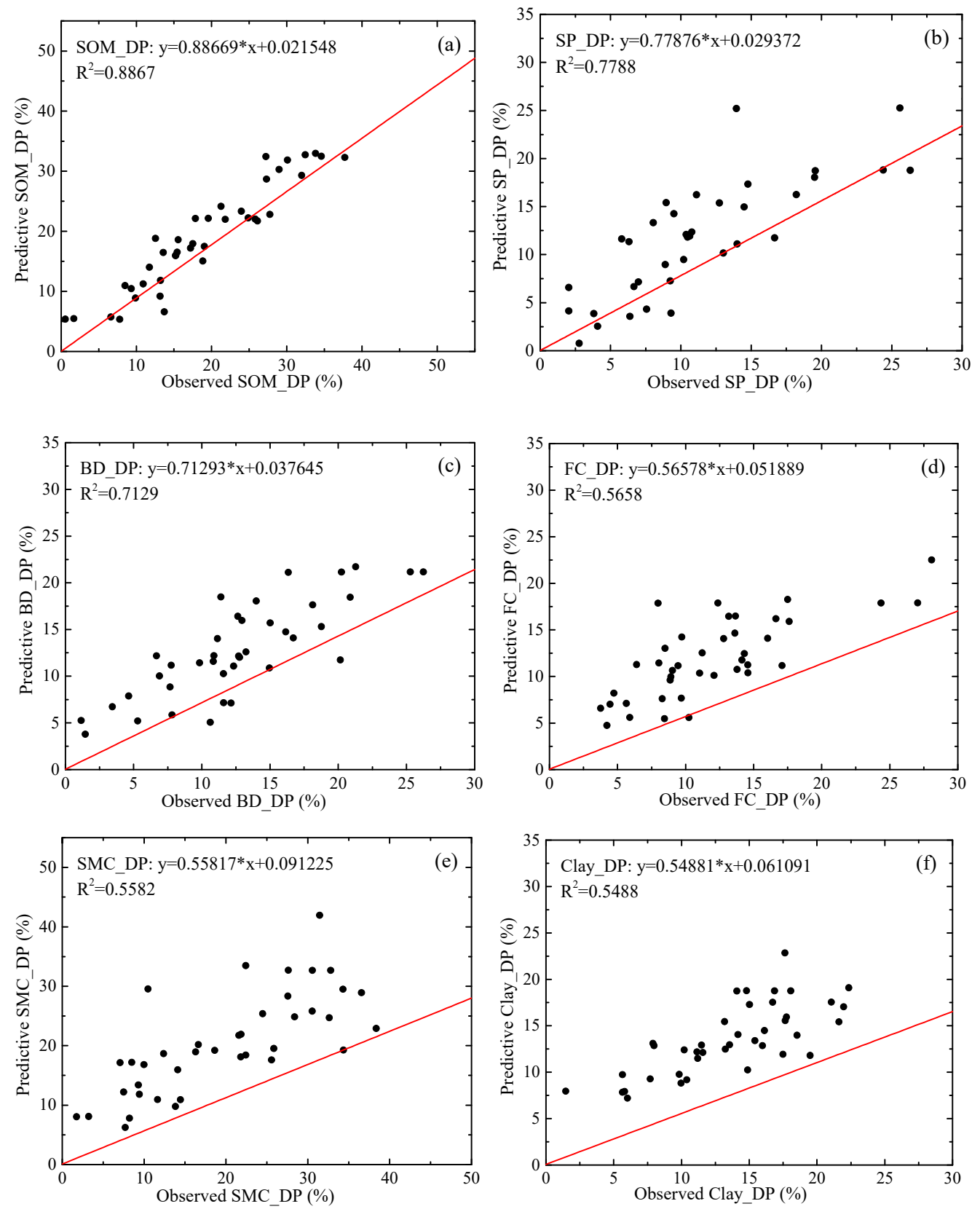

Figure 5. Accuracy performance of BP neural network model for quantitative relationships between ground fissures and changes in soil properties. (a) SOM, soil organic matter; (b) SP, soil porosity; (c) BD, bulk deny; (d) FC, field capacity; (e) SMC, soil moisture content; (f) Clay, percent clay; DP, the percentage of the difference. 


\section{Discussion}

\subsection{Impacts of Ground Fissures on Soil Properties}

Ground fissures mainly caused observed decline in the physical properties. In this research, the soil properties at the edge points of ground fissures, including SOM, SMC, $\mathrm{BD}, \mathrm{FC}$, and Clay, were found to be significantly less than those of the contrast points (Figure 3). This could have been caused by the following three factors. (1) Ground fissures directly enlarge the exposed area of the surface soil and accelerate soil evaporation and wind erosion, leading to a decrease of SMC. (2) The increase in surface slope caused by mining subsidence accelerates the intensity of precipitation runoff, making the soil at the edge of ground fissures more susceptible to rain erosion, thereby exacerbating the loss of soil and nutrients [17]. (3) The plant communities near ground fissures were impaired by ground movement, and vegetation coverage decreased, thereby weakening the ability of vegetation on controlling soil erosion and stabilizing fertility [30,31]. Based on the mechanism involved in the formation of ground fissures, the fissures can be divided into tensile, compressed, collapsed, and sliding ground fissures [32,33], which would impact the soil properties around ground fissures in different ways. For instance, collapsing and sliding cracks have obvious surface fluctuations caused by the large gap that expand between the ground fissures, which reduces the intensity of surface runoff to a certain extent [34]; pressure and stress from the sides of ground fissures compress the soil around the cracks, thus leading to an increase in bulk density and a decrease in soil porosity [14]. Moreover, changes in soil properties would limit the growth of plant as succession of communities, which further accelerate the degradation of soil around ground fissures. The ground fissures investigated in this paper were mainly tensile fissures, which are prone to collecting water from surface runoff, and the edge of ground fissures could also be eroded by heavy rainfall.

\subsection{Correlations between Ground Fissures and Changes in Soil Properties}

Changes in soil properties is closely related to the width, slope, and vegetation coverage of the ground fissures. In this research, the positive correlation between the changes of soil properties at the edge points with the width and slope of ground fissures, along with the negative collection with vegetation coverage (Tables 2 and 3) could be caused by the increase in the slope of the ground fissures accelerating the speed of precipitation runoff, which intensifies soil erosion. The increase in width intensifies air flow on the fractured slope surface, leading to an increase in the rate of water evaporation; it also strengths the ability of ground fissures in intercepting runoff, enabling more water with nutrients to penetrate into deep soil [35]. Conversely, increased vegetation coverage around the cracks enhances the soil's ability to retain water and fertility as well as to slow the speed of runoff from rain, preventing an increase in soil erosion [36]. The RDA results show that vegetation coverage is the most important factor in determining the changes of soil properties, and it is closely related to the $S_{i_{2}} D P$. However, the cumulative explanations of the total variation of $\mathrm{S}_{\mathrm{i}_{-}} \mathrm{DP}(74.81 \%)$ and $\mathrm{S}_{\mathrm{i}_{-}} \mathrm{DV}(49.6 \%)$ via selected characteristics of ground fissures were relatively low, indicating that there could be other factors influencing the changes of soil properties. In previous research, the density of ground fissures within an area was also considered as a factor that influenced soil properties [25]. This indicated that the interaction between adjacent ground fissures and changes in regional terrain could also affect soil properties. A lower correlation of $\mathrm{S}_{\mathrm{i}_{-}} \mathrm{DV}$ with ground fissures than that of $\mathrm{S}_{\mathrm{i}_{-}} \mathrm{DP}$ also indicated the initial soil properties can also influence the level of changes in soil properties, and thus a pre-survey on basic soil properties of the area with ground fissures should be performed before land reclamation and ecological restoration.

\subsection{Applications of Quantitative Relationships between Ground Fissures and Changes in Soil Properties}

Quantitative relationships between ground fissures and changes in soil properties would provide cost-effective method for environmental impacts assessment in mining area 
on a large scale. On the Loess Plateau, the subsidence induced from underground mining usually cover a large area, and it would be hardly to perform field survey to investigate mining-impacts in such a ravine area with complex topography [37]. Therefore, it is necessary to apply remote sensing for a rapid environmental impacts assessment, especially the images with high-resolution acquired by unmanned aerial vehicles. Some previous research put forward various models for the retrieval of soil moisture [38], organic matter [39], and salinity [40], however, most of them used those UAVs carried with multispectral cameras, which are very more expensive, and have higher standards in manipulating, carrying as well as processing than consumer UAVs usually carried with RGB cameras. In this research, quantitative relationships between ground fissures and changes in soil properties were demonstrated, which can be used for evaluation of mining-impacts on soil properties with characteristics of ground fissures, and thus consumer UAVs would be capable enough. As shown in Figure 6, an images that acquired from study area by consumer UAV was used to detect edges points of ground fissures via image edge detection algorithm [41], and it can be further processed to obtain the width, slope, and plant coverage of ground fissures with digital elevation model images. After that, the changes in soil properties caused by ground fissures would be quantified and mapped with quantitative relationships demonstrated in this research.

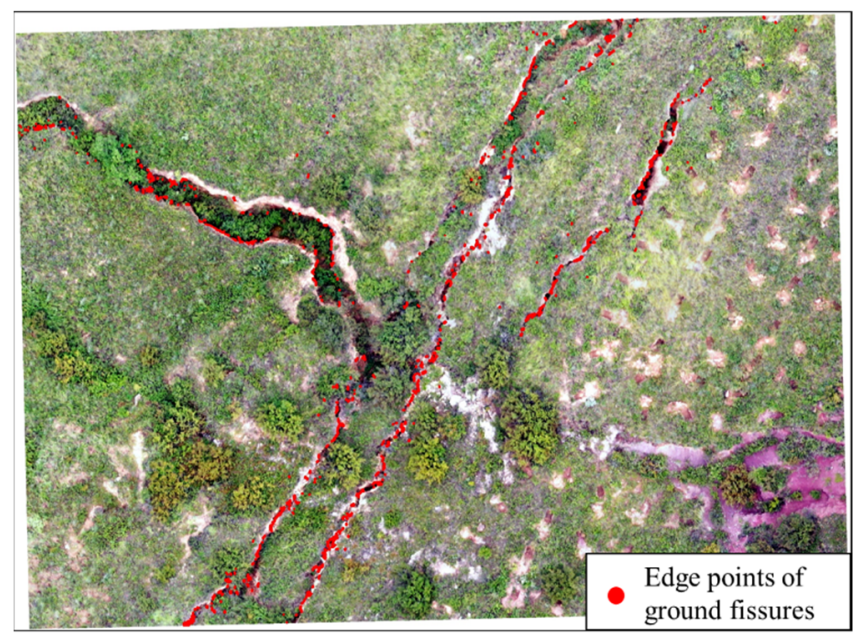

Figure 6. Edges points of ground fissures determined by a UAV image acquired from study area.

\subsection{Limitations and Future Work}

There are some limitations to this study, causing a relatively low accuracy in the simulation of the changes in soil properties via characteristics of ground fissures. In this research, the width, length, depth, slope, and vegetation cover of ground fissures were selected to be analyzed for the correlation with changes in soil properties. However, as we mentioned in last section, some other factors may influence the degree of changes in soil properties, such as rainfall, wind, and soil initial conditions, as well as the location and interaction between ground fissures. For example, due to the difference in wind speed and precipitation runoff, the ground fissures in different positions on a slope may have different amounts of soil erosion and nutrient loss; meanwhile, the changes in soil properties occurring at different locations of the same ground fissure may also show spatial differences [42]. On the other hand, the soil type is also an important factor influencing the degree of changes in soil properties induced from ground fissures, which could make the quantitative relationship found in this research only applied in the area with similar soil substrate. All these factors could limit the accuracy of determining changes in soil properties quantitatively via characteristics of ground fissures.

In future research, the quantitative relationship between ground fissures and changes in soil properties should be further demonstrated with considering all other factors influencing soil properties. Besides those factors mentioned such as rainfall, the interaction 
between adjacent ground fissures should be further researched. The surface runoff from precipitation is a critical factor driving changes in soil properties, while the rate and amount of runoff would be reduced by ground fissure. Moreover, the number, locations, and angles of ground fissures on a slope, as well as their distances to each other, would all change the runoff, and the changes in soil properties will also be influenced. Therefore, the relationships between ground fissures and changes in soil properties should be further explored, especially the variance of the changes in soil properties near each individual ground fissure and the interaction between several ground fissures.

\section{Conclusions}

Mining-induced ground fissures on the Loess Plateau have caused the alteration of various soil properties, with changes in soil properties found to be related to the width, slope, and vegetation coverage of a ground fissure. In the Yungang mining area, most of the soil properties at the edge point of the ground fissures were found to have smaller values than those at the contrast points. These properties included soil organic matter, moisture content, bulk density, field capacity, and clay content, while the soil porosity at the edge point was greater. The average percentage of the difference between the edge and contrast points of ground fissures in these six properties was $15.27 \%$, and the SMC showed the greatest change $(20.65 \%)$. Vegetation coverage was the most important factor determining the degree of changes in soil properties according to the results of redundancy analysis. The quantitative relationship between characteristics of ground fissures (width, slope, and vegetation coverage) and the change in soil organic matter by BP neural network model had the highest accuracy $\left(R^{2}=0.89\right)$, followed by those between ground fissures and the changes in soil porosity $\left(R^{2}=0.78\right)$ and bulk density $\left(R^{2}=0.71\right)$, and all others were also above 0.5 . The findings of this research could provide a method for a quick assessment of changes in soil properties induced from ground fissures in mining areas; however, the application of quantitative relationships between ground fissures and changes in soil properties in environmental assessment on a large scale will require further research.

Supplementary Materials: The following supporting information can be downloaded at: https: / / www.mdpi.com/article/10.3390/land11020162/s1, Table S1: Characteristics of ground fissures.

Author Contributions: Conceptualization, J.M. and Y.Y.; resources J.M., Y.Y., H.H. and S.Z.; writingoriginal draft preparation, J.M.; writing-review and editing, Y.Y., H.H., S.Z. and Z.D.; funding acquisition, S.Z. and Y.H. All authors have read and agreed to the published version of the manuscript.

Funding: The research was funded by the National Natural Science Foundation of China, grant Number 51874307, and Postgraduate Research \& Practice Innovation Program of Jiangsu Province grant Number KYCX19_2146, as well as Postgraduate Research \& Practice Innovation Program of China University of Mining and Technology, grant Number KYCX19_2146.

Institutional Review Board Statement: Not applicable.

Informed Consent Statement: Not applicable.

Data Availability Statement: The data presented in this study are available in the Supplementary Material.

Conflicts of Interest: The authors declare no conflict of interest.

\section{References}

1. Dawei, Z.; Kan, W.; Zhihui, B.; Zhenqi, H.; Liang, L.; Yuankun, X.; Xinpeng, D. Formation and development mechanism of ground crack caused by coal mining: Effects of overlying key strata. Bull. Eng. Geol. Environ. 2019, 78, 1025-1044. [CrossRef]

2. $\mathrm{Wu}, \mathrm{Q} . ; \mathrm{Liu}, \mathrm{S}$. The classification of mine environmental geology problems in China. Environ. Earth Sci. 2010, 64, 1505-1511. [CrossRef]

3. Yang, Y.J.; Erskine, P.D.; Zhang, S.L.; Wang, Y.J.; Bian, Z.F.; Lei, S.G. Effects of underground mining on vegetation and environmental patterns in a semi-arid watershed with implications for resilience management. Environ. Earth Sci. 2018, $77,605$. [CrossRef]

4. Yang, X.L.; Wen, G.C.; Dai, L.C.; Sun, H.T.; Li, X.L. Ground Subsidence and Surface Cracks Evolution from Shallow-Buried Close-Distance Multi-seam Mining: A Case Study in Bulianta Coal Mine. Rock Mech. Rock Eng. 2019, 52, 2835-2852. [CrossRef] 
5. Ma, K.; Zhang, Y.X.; Ruan, M.Y.; Guo, J.; Chai, T.Y. Land Subsidence in a coal mining area reduced soil fertility and led to soil degradation in arid and semi-arid regions. Int. J. Environ. Res. Public Health 2019, 16, 3929. [CrossRef]

6. Jing, Z.R.; Wang, J.M.; Zhu, Y.C.; Feng, Y. Effects of land subsidence resulted from coal mining on soil nutrient distributions in a loess area of China. J. Clean. Prod. 2018, 177, 350-361. [CrossRef]

7. Wang, Z.; Wang, G.; Zhang, Y.; Wang, R. Quantification of the effect of soil erosion factors on soil nutrients at a small watershed in the Loess Plateau, Northwest China. J. Soils Sed. 2020, 20, 745-755. [CrossRef]

8. Mi, J.X.; Liu, R.; Zhang, S.L.; Hou, H.; Yang, Y.; Chen, F.; Zhang, L. Vegetation patterns on a landslide after five years of natural restoration in the Loess Plateau mining area in China. Ecol. Eng. 2019, 136, 46-54. [CrossRef]

9. Du, T.; Bi, Y.; Gao, F.; Lv, W. Effects of surface cracks on the rhizospheric microhabitat of Artemisia ordosica in subsidence area caused by coal mining. J. Coal Sci. Eng. 2013, 19, 231-236. [CrossRef]

10. Bi, Y.L.; Xie, L.L.; Wang, J.; Zhang, Y.X.; Wang, K. Impact of host plants, slope position and subsidence on arbuscular mycorrhizal fungal communities in the coal mining area of north-central China. J. Arid Environ. 2019, 163, 68-76. [CrossRef]

11. Wang, Y.; Bian, Z.; Lei, S.; Zhang, Y. Investigating spatial and temporal variations of soil moisture content in an arid mining area using an improved thermal inertia model. J. Arid Land 2017, 9, 712-726. [CrossRef]

12. Zou, H.; Bi, Y.; Zhu, C.; Du, T.; Han, B. Effect of mining subsidence on soil moisture dynamic changes of sandy land. J. China Univ. Min. Technol. 2014, 43, 21. [CrossRef]

13. Xu, C.; Ma, S.; Zhang, H.; Wang, R.; Guan, Z. Effect of cracks on soil characteristics and crop growth in subsided coal mining areas. Chin. J. Eco-Agric. 2015, 23, 597-604. [CrossRef]

14. Wang, J.M.; Wang, P.; Qin, Q.; Wang, H.D. The effects of land subsidence and rehabilitation on soil hydraulic properties in a mining area in the Loess Plateau of China. Catena 2017, 159, 51-59. [CrossRef]

15. Wang, J.M.; Zhang, J.R.; Feng, Y. Characterizing the spatial variability of soil particle size distribution in an underground coal mining area: An approach combining multi-fractal theory and geostatistics. Catena 2019, 176, 94-103. [CrossRef]

16. Bi, Y.L.; Zou, H.; Zhu, C.W. Dynamic monitoring of soil bulk density and infiltration rate during coal mining in sandy land with different vegetation. Int. J. Coal Sci. Technol. 2014, 1, 198-206. [CrossRef]

17. Peng, J.B.; Wang, F.Y.; Cheng, Y.X.; Lu, Q.Z. Characteristics and mechanism of Sanyuan ground fissures in the Weihe Basin, China. Eng. Geol. 2018, 247, 48-57. [CrossRef]

18. Luo, Z.; Ma, J.; Chen, F.; Li, X.; Hou, H.; Zhang, S. Cracks Reinforce the Interactions among Soil Bacterial Communities in the Coal Mining Area of Loess Plateau, China. Int. J. Environ. Res. Public Health 2019, 16, 4892. [CrossRef] [PubMed]

19. Shi, P.L.; Zhang, Y.X.; Hu, Z.Q.; Ma, K.; Wang, H.; Chai, T.Y. The response of soil bacterial communities to mining subsidence in the west China aeolian sand area. Appl. Soil Ecol. 2017, 121, 1-10. [CrossRef]

20. Mohseni, N.; Sepehr, A.; Hosseinzadeh, S.R.; Golzarian, M.R.; Shabani, F. Variations in spatial patterns of soil-vegetation properties over subsidence-related ground fissures at an arid ecotone in northeastern Iran. Environ. Earth Sci. 2017, 76, 234. [CrossRef]

21. Liu, S.L.; Li, W.P.; Qiao, W.; Wang, Q.Q.; Hu, Y.B.; Wang, Z.K. Effect of natural conditions and mining activities on vegetation variations in arid and semiarid mining regions. Ecol. Indicators 2019, 103, 331-345. [CrossRef]

22. Lechner, A.M.; Baumgartl, T.; Matthew, P.; Glenn, V. The Impact of underground longwall mining on prime agricultural land: A review and research agenda. Land Degrad. Dev. 2016, 27, 1650-1663. [CrossRef]

23. Sun, W.Y.; Song, X.Y.; Zhang, Y.Q.; Chiew, F.; Post, D.; Zheng, H.X.; Song, S.B. Coal mining impacts on baseflow detected using paired catchments. Water Resour. Res. 2020, 56, e2019WR025770. [CrossRef]

24. Dejun, Y.; Zhengfu, B.; Shaogang, L. Impact on soil physical qualities by the subsidence of coal mining: A case study in Western China. Environ. Earth Sci. 2016, 75, 652. [CrossRef]

25. Ma, Y.B.; Gao, Y.; Zhang, Y.; Dong, J.; Huang, Y.R. Study on soil moisture surrounding coal mining subsidence crack in semi-arid region. Adv. Mater. Res. 2013, 726-731, 3883-3887. [CrossRef]

26. Mi, J.X.; Yang, Y.J.; Zhang, S.; An, S.; Hou, H.; Hua, Y.; Chen, F. Tracking the land Use/land cover change in an area with underground mining and reforestation via continuous Landsat classification. Remote Sens. 2019, 11, 1719. [CrossRef]

27. Pidgeon, J. The measurement and prediction of available water capacity of ferralitic soils in Uganda. J. Soil Sci. 1972, 23, 431-441. [CrossRef]

28. Bremner, J.M. Total Nitrogen. In Methods of Soil Analysis Part 2. Chemical and Microbiological Properties; Norman, A.G., Ed.; American Society of Agronomy: Madison, GA, USA, 1982; pp. 1149-1178.

29. Tyler, S.W.; Wheatcraft, S.W. Fractal Scaling of Soil Particle-Size Distributions: Analysis and Limitations. Soil Sci. Soc. Am. J. 1992, 56, 362-369. [CrossRef]

30. Wang, L.; Wei, S.; Horton, R.; Shao, M.a. Effects of vegetation and slope aspect on water budget in the hill and gully region of the Loess Plateau of China. Catena 2011, 87, 90-100. [CrossRef]

31. Bi, Y.L.; Zhang, J.; Song, Z.H.; Wang, Z.G.; Qiu, L.; Hu, J.J.; Gong, Y.L. Arbuscular mycorrhizal fungi alleviate root damage stress induced by simulated coal mining subsidence ground fissures. Sci. Total Environ. 2019, 652, 398-405. [CrossRef]

32. Zhu, H. Development mechanism of mining-induced ground fissure for shallow burial coal seam in the mountains area of southwestern China: A case study. Acta Geodyn. Geomater. 2018, 15, 349-362. [CrossRef]

33. Liu, H.; Deng, K.; Zhu, X.; Jiang, C. Effects of mining speed on the developmental features of mining-induced ground fissures. Bull. Eng. Geol. Environ. 2019, 78, 6297-6309. [CrossRef] 
34. Liu, H.; Deng, K.; Lei, S.; Bian, Z. Mechanism of formation of sliding ground fissure in loess hilly areas caused by underground mining. Int. J. Coal Sci. Technol. 2015, 25, 553-558. [CrossRef]

35. Lu, Q.; Liu, Y.; Peng, J.; Li, L.; Fan, W.; Liu, N.; Sun, K.; Liu, R. Immersion test of loess in ground fissures in Shuanghuaishu, Shaanxi Province, China. Bull. Eng. Geol. Environ. 2020, 79, 2299-2312. [CrossRef]

36. Zhang, L.; Wang, J.; Bai, Z.; Lv, C. Effects of vegetation on runoff and soil erosion on reclaimed land in an opencast coal-mine dump in a loess area. Catena 2015, 128, 44-53. [CrossRef]

37. Hou, H.; Ding, Z.; Zhang, S.; Guo, S.; Yang, Y.; Chen, Z.; Mi, J.; Wang, X. Spatial estimate of ecological and environmental damage in an underground coal mining area on the Loess Plateau: Implications for planning restoration interventions. J. Clean. Prod. 2021, 287, 125061. [CrossRef]

38. Luo, W.; Xu, X.; Liu, W.; Liu, M.; Li, Z.; Peng, T.; Xu, C.; Zhang, Y.; Zhang, R. UAV based soil moisture remote sensing in a karst mountainous catchment. Catena 2019, 174, 478-489. [CrossRef]

39. Angelopoulou, T.; Tziolas, N.; Balafoutis, A.; Zalidis, G.; Sensing, D.B.J.R. Remote Sensing Techniques for Soil Organic Carbon Estimation: A Review. Remote Sens. 2019, 11, 676. [CrossRef]

40. Hu, J.; Peng, J.; Zhou, Y.; Xu, D.; Shi, Z.J.R.S. Quantitative Estimation of Soil Salinity Using UAV-Borne Hyperspectral and Satellite Multispectral Images. Remote Sens. 2019, 11, 736. [CrossRef]

41. Xu, D.; Zhao, Y.; Jiang, Y.; Zhang, C.; Sun, B.; He, X. Using Improved Edge Detection Method to Detect Mining-Induced Ground Fissures Identified by Unmanned Aerial Vehicle Remote Sensing. Remote Sens. 2021, 13, 3652. [CrossRef]

42. Zhang, H.; Liu, W.; Zhang, H.; Fan, L.; Ma, S. Spatial distribution of soil organic matter in a coal mining subsidence area. Acta Agric. Scand. Sect. B-Soil Plant Sci. 2019, 70, 117-127. [CrossRef] 